\title{
CULTURAL ASPECT OF SENTIMENTAL TOURISM WITHIN UKRAINIAN-POLISH BORDER
}

\author{
Vitaliy KOZOVIY* \\ Lviv State University of Physical Culture, Faculty of Tourism, Department \\ of Tourism, Kostyshka Street 11, Lviv, Ukraine, e-mail: Live-Love@ukr.net
}

\begin{abstract}
Citation: Kozoviy, V. (2018). CULTURAL ASPECT OF SENTIMENTAL TOURISM WITHIN UKRAINIAN-POLISH BORDER. GeoJournal of Tourism and Geosites, 23(3), 668-674. https://doi.org/10.30892/gtg.23304-318
\end{abstract}

\begin{abstract}
Ukrainian cultural heritage in Poland and Polish on the territories of Ukraine (especially western oblasts) create a potent base in expanding of sentimental tourism. Interaction of past periods between Ukraine and Poland, mutual history and tourist's family affair, motivate to travel with such a goal. These events left a particular trace, for instance: proper history facts in books and various touristic objects (historical and cultural memorials) on the western side of Ukraine and eastern side of Poland. This work should represent the main aim of sentimental tourism, the definition from various scientists, personal investigation wich leads to a better understanding of such trip. The methods of research: theoretical, historical, graphical, analysis and synthesis of the literature, survey. Results: the concept of sentimental tourism from different scientists is given; characteristic of Ukrainian-Polish areas in table and map is included; the results of own investigation (survey of respondents) in tables and diagrams is provided.
\end{abstract}

Key words: sentimental tourism, Ukrainian-Polish border, Lviv, memorials, culture, relatives

\section{INTRODUCTION}

Sentimental tourism, as well as tourism in general, is the property of the whole state and a block of colossal income, advertising and tourist attractions, it is impossible to mention in general, this is understandable. Such tourism, in particular, stimulates friendship among people. As far as friendship with Russia is concerned, the question is controversial, but with Poland and other countries - foremost. As centuries passed, to begin with, various nations came to find Ukraine as the second motherland, nations, who were haunted for their religion, politic and some other believes, craving better conditions for living. In such case, most of them amplified culture (traditions) of nation and country (Kalinowski \& Jacov, 2015).

\section{DISCUSSIONS}

Sentimental tourism is a type of travel in wich the great aim is to come with specific emotions of tourists, knowing as "nostalgia" (Kuzik, 2010). The trait of it is to visit

\footnotetext{
* Corresponding author
} 
familiar places of the past, ancestors' existence, childhood and birthplaces. Sentimental tourism rearranges the national moral and raises patriotic feelings. At a point, those people were forced to separate with their families or motherland (Kuzik, 2010).

Equivalent, in the American literature is "the roots syndrome tourism" or "ethnic tourism". This kind of tourism has existed since a long time, but in East Central Europe it was recently intensified and become important income source. The subject of the sentimental tourism is a specific group of people who once have left their country for good (Baraniecki \& Wisniowa, 2011).

In modern scientific literature there's a widely use of this term but its importance in tourism geography is not quite expanded. For example: Polish scientist TomczewskaPopowycz N. I. give such definition "sentimental tourism is a kind of trip the main goal of which is to come back to the places which force to feel specific feelings of nostalgia" The main base of it is a cultural and historical heritage (Tomczewska-Popowycz, 2016) Sentimental tourism deals with terms such as: "sentiments", "national minority", "Ukrainian diaspora", "ethnic lands and borderline", "leftover".

Sentiments are a loose of human senses and feelings. In the first place, nostalgic feeling is a principle of sentimental tourism (Kuzik, 2010).

National minority is the citizen group with their (ethnic, religion and language) characteristics which differ from other citizens. These groups of people are numerically smaller within one country (Shapoval, 2006).

Ukrainian diaspora is a category of people of Ukrainian descent who live outside Ukraine and foreign ukrainians that liaise with their families (Shapoval, 2006).

Ethnic lands is the territories where historically formed groups of people spoke certain language, honor their common traditions, culture and history (Shapoval, 2006).

Ethnic borderline are the lines of demarcation of ethnic territory which are not stable and change under the influence of political factors, often with the use of military force, by ethnocide (Shapoval, 2006).

Leftover is the cultural relics (results of human evolution, history etc). A kind of human's work and believes from generation to generation (Shapoval, 2006).

In retrospect, when Ukraine proclaimed its independence in 1991, it had influenced on routine, dare say, of polish ethnic group on the western Ukraine. Lots of polish cultural associations had been created and schools that had been opened in Ukrainian cities. Poles, Germans, Jews - all these tourists make possible to develop sentimental tourism. Ethnic mosaic of some region had been lasted for ages. In fact, when Poles occupied Galicia they had been lived there 400 years and intended to come to stay in Ukraine. However, it didn't work out. Nowadays Lviv, Zhovkva, Zolochiv (Lviv Oblast), KamianetsPodilskyi (Khmelnitsky Oblast), - have become centers of sentimental tourism, they're close enough to the Polish border. Before Ukrainians deportation, before the Second World War, from the whole population of Lviv, $70 \%$ of them - were Poles, in 1989 - 1,2 $\%$ and in $2001-0,7 \%$ (19 thousand people). In the past, Poles travel massively, especially those, which were born and lived on the western Ukraine (Pecarchuk, 2011).

A lot of polish amateur tourist organization in Lviv such as TOWARZYSTWO MIŁOŚNIKÓW LWOWA manage to interest with their sentimental trips, visiting noble locations with polish culture and many more. Here are some of them: Lychakiv cemetery (Lviv) where buried famous Poles (Wladyslaw Belza - a writer (1913); Maria Konopnicka - a journalist and poet (1910); Juliusz Konstanty Ordon - a participant and hero of Polish November Uprising (1887), Gabriela Zapolska - a novelist and actress (1921), Karol Szajnoca - an historian and writer (1868), Artur Grottger - the painter (1867) etc) (Pecarchuk, 2011). Lychakiv cemetery, where the burial place of the Lviv eaglets was also destroyed after the Second World War, however, in 2005 the efforts of 
the presidents of Poland and Ukraine were reopened (Tomczewska-Popowycz, 2016). Cemetery of the Defenders of Lviv (also: Cemetery of the Eaglets) - an autonomous part of the Lychakiv cemetery in Lviv. It occupies a separate place - the slopes of the hills from the Pohulanka side. There are graves of the participants of the battle for Lviv and Małopolska Wschodnia, who died in 1918-1920 or died in later years. It is often called the Eaglets' Cemetery; since almost 3,00o soldiers buried there, some of them are Orlęta Lwowskie, that is, high school and higher school students, and intelligence. He was called a holy place by the Poles (Campo Santo). World war soldiers from different countries also buried there. Ukraine spared monuments to some of Poles: Martinivka village (Cherkasy oblast) - a memorial room and monument to an activist Ludwik Warynski who was born there; Lviv - a monument to a poet and political activist Adam Mickiewicz, dated 1904 (Kuzik, 2010). Poles architects worked in Lviv: Piotr Barbon (Piotr Beber) reconstructed the Lviv Town Hall, Korniakt Tower (the part of Dormition Church) and also, the Castle in Zhovkva city (Lilio, etal., 2007). In fact, Lviv is the city with the richest and highest level of touristic objects (heritage) within Ukrainian-Polish border. Public architecture took the first place for its importance in Lviv Oblast, in which it takes $20 \%$, also military architecture with 12 objects (Kuzik, 2010). In 2003 Volyn Oblast carried 30 monuments of history and culture, 4 of them - were polish (Pecarchuk, 2011).

There is the law on the Ukraine territory "On the protection of cultural heritage", which divides into 10 chapters and consists 49 articles. This law regulates various relations (social, economic) in the field of cultural heritage protection in order to preserve them in the interests of present and further generations (www.zakon2.rada.gov.ua). Furthermore, we can mention «Agreement between Ukraine and Poland about legal regime of Ukrainian-Polish border and common cooperation (www.zakono.rada.gov.ua).

Ukrainian-Polish border is a territory which covers a couple of administrative regions across the borderline of two countries. The length of the border is $535 \mathrm{~km}$. The borderline area is $85018 \mathrm{~km}^{2}$, the Ukrainian side covers $41977 \mathrm{~km}^{2}$ and Polish - 43041 $\mathrm{km}^{2}$ (Miszczuk, 2002; Więckowski, 2010). The Ukrainian districts, (especially Lviv and Volyn), have very good conditions for the development of agriculture, and hence this sector of the economy is significant for them, it has quite a traditional structure in Volyn oblast, while in Lviv it undergoes restructuring, owing in particular to the inflow of foreign capital (Komornicki \& Miszcuk, 2010). Within borderlands, tourism has become the most important branch of the economy and one that is often treated as the sole opportunity for development at the same time becoming the primary domain of integration (Krawczyk, 2005). Polish scientist A. Fedun (Fedun, 2001) had a particular investigation "Main directions of Ukrainian-Polish border cooperation in the conditions of the European integration process" in this field and determined 4 administrative units within Ukrainianpolish border (Table 1): Territories of Ukrainian-Polish border (Fedun A. Main directions of Ukrainian-Polish border cooperation in the conditions of the European integration process, 2001). These administrative units can be seen on the map (Figure 1).

Table 1. Territories of Ukrainian-Polish border

\begin{tabular}{|c|c|c|}
\hline № & Administrative area & Country \\
\hline 1. & Lublin Voivodeship & \multirow{2}{*}{ Poland } \\
2. & Podkarpackie Voivodeship & Uolyn Oblast \\
\hline 1. & Lviv Oblast & Ukraine \\
\hline
\end{tabular}

Andriy Matseliuk a head of Lviv association of tourism development made a basic touristic plan to develop this type of tourism on the mentioned territories in 2014 . 
Regional growth agency in Przemysl (Poland) interacted as a strategic partner of the program. As the matter of fact, this case deals with promotion of touristic potential (heritage) of Lviv Oblast, Podkarpackie Voivodeship and Lublin Voivodeship. The main course of this partnership was to unit two countries with common intentions in touristic sphere also an extensive presentation of their product. Due to historical events, borderline change, mass deportation of people, sentimental tourism is a popular one within the confines of Ukrainian-Polish border (Shapoval, 2006).

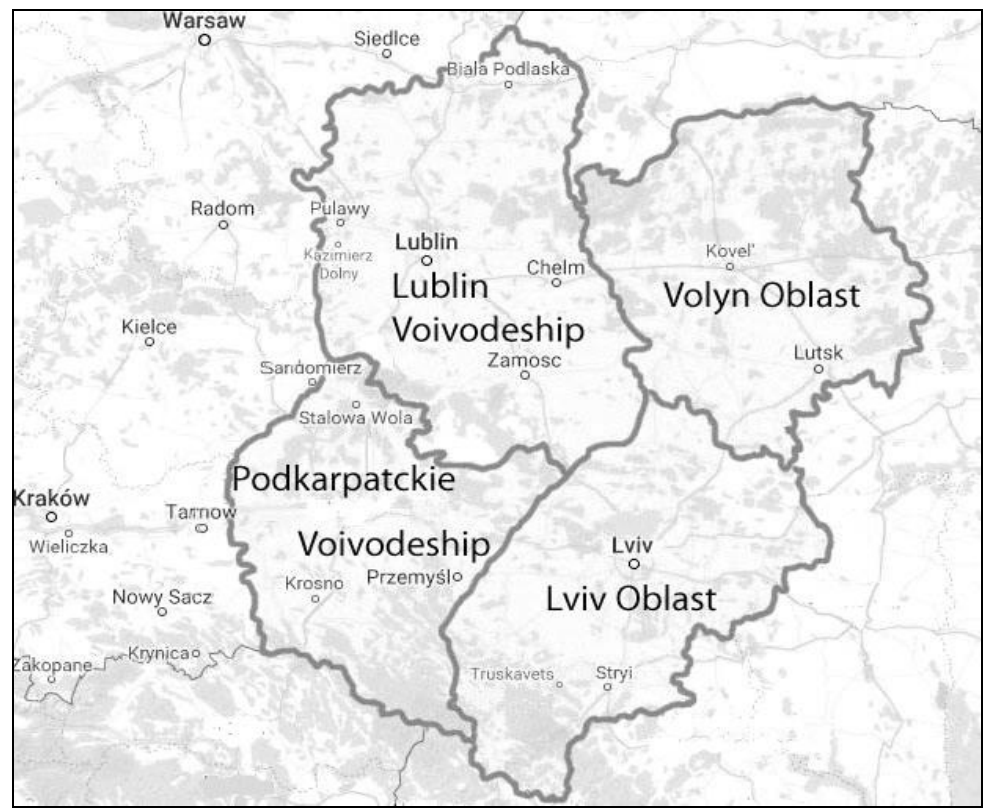

Figure 1. Territories of Ukrainian-Polish border on map (www.google.com/maps/places, 2017)

After deportations, the number of Ukrainians on Polish lands (Chelm land, Nadsanie, Podlachia, Lemkivshchyna) has decreased. Most Ukrainians from those regions were resettled in the western regions of Ukraine (about 483 thousand people). Before Operation Vistula ukrainians were forbidden to live closer than $50 \mathrm{~km}$ to the western border with Poland. Taking into account the past relations with Poland, a kind of "ethnic offence" was formed in Ukrainians. Ethnic offence is an emotional-expressive feeling that memory remains as a result of past pressure of other society (Shapoval, 2006).

These principles no longer exist today. The biggest concentration of Ukrainians in Poland are in Warsaw (approximately 10 thousand of people) and in Krakow (approximately 3 thousand) and other cities. 20 thousand of Ukrainians live in Poland (Shabliy, 2004). According to Wikipedia resource, in 2011 more than 50 thousand of Ukrainians lived in Poland and in 2017 there were about 1 million of Ukrainians (www.wikipedia.com). Ukrainian lyceums have been formed, institutes for the training of Ukrainian teachers are in operation, and different departments have been opened in Warsaw, Lublin, Krakow universities (Shabliy, 2004). Ukrainian people emigrate in order to find better conditions for living and also they can keep contact with their family. Ukraine is leading the level of labor migration. This fact is explained by an increasingly tense situation within the state, low wages and a standard of living and also a cultural factor (Tomczewska-Popowycz, 2016). The concept of emigration indicates a temporary departure and a short stay of an individual outside of his native land. The modern borders of Ukraine 
are ethno-historical and are beyond its borders, and the Ukrainian diaspora exists in the form of various ethno-real communities in another environment (Savchuk, 2004).

Borders can be used as tourist attractions, so in this case, sentimental tourism is the right example. Some people cross borders just so they can claim that they have been in a different country. The development of tourism in these areas is associated highly with the processes of modernization, globalization, integration (Więckowski, 2010).

Survey investigation was made. It gas been lasted for one month. For that time 115 students of 3 Lviv's universities (Ivan Franko National University; Lviv Polytechnic National University; Lviv State University of Physical Culture) were questioned in the form of a questionnaire, 17-20 years old. Such questions were given:

1. Do you have family or family roots in Poland?

2. In which city your family live?

3. What was the reason of your family to stay in Poland?

4. How often do you visit them?

5 . Do you plan to go to Poland in the nearest future?

The results of the investigation have been tabulated and diagramed (Table 2):

Table 2: How many of respondents have relatives in Poland

\begin{tabular}{|c|c|c|}
\hline № & The presence of family roots in Poland & The number of respondents \\
\hline 1. & There are relatives in Poland & 30 \\
\hline 2. & There are not relatives in Poland & 75 \\
\hline 3. & Not aware & 10 \\
\hline
\end{tabular}

The results of investigation from table 2 in diagram:

1. 30 respondents have family in Poland (the blue part);

2. 75 respondents do not have family in Poland (the purple part);

3. 10 respondents so far not aware (the yellow part).

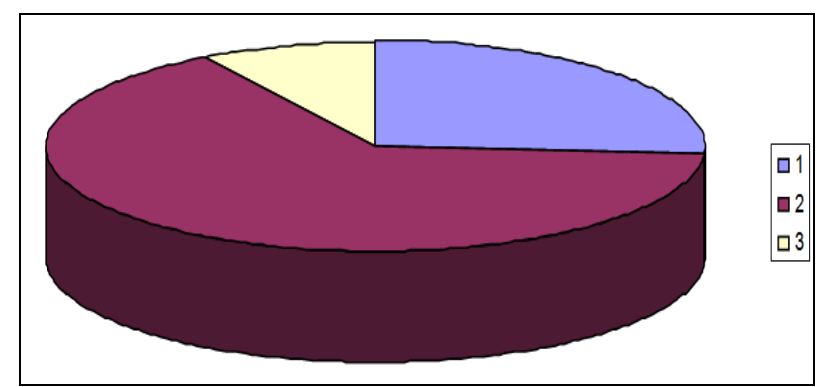

Figure 2. How many of respondents have relatives in Poland in diagram

Table 3. Poland cities where respondents' families live

\begin{tabular}{|c|c|}
\hline № & City \\
\hline 1. & Gdansk \\
\hline 2. & Krakow \\
\hline 3. & Lodz \\
\hline 4. & Lubachow \\
\hline 5. & Lublin \\
\hline 6. & Tomaszow \\
\hline 7. & Warsaw \\
\hline 8. & Wroclaw \\
\hline 9. & Zamosc \\
\hline
\end{tabular}


More than 70 students do not have family in Poland but it doesn't mean that they wouldn't go to visit Poland. 10 of respondents are not aware with the fact that they have someone there or hard to tell at the particular moment. 30 students generally visit their family and list of the Poland cities you can find in Table 3. The next one gives an information about possibility of visiting Poland in the nearest future, on the Figure 3 it can be seen in diagram.

1. 103 students are planning to go to Poland (the blue part);

2. 12 students do not (the purple part).

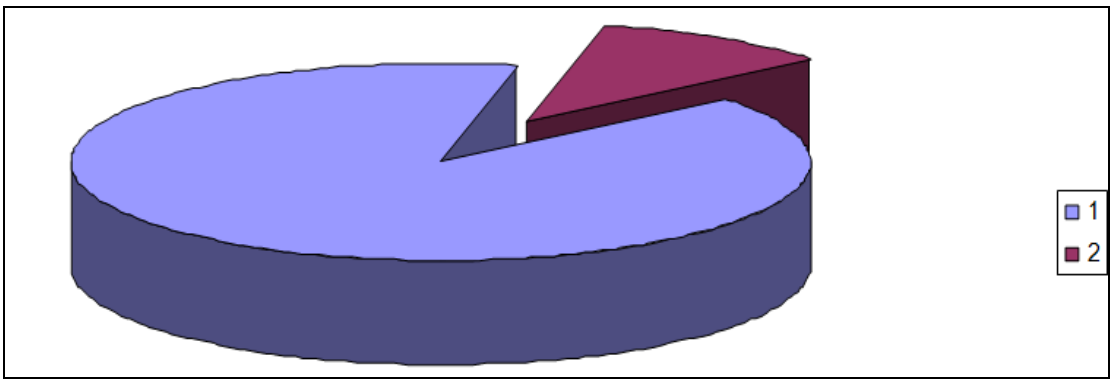

Figure 3. A possibility to visit Poland in the nearest future (2017)

The purpose of such trips is mainly short-term visits and meetings with relatives. A dozen respondents said that the family was in Poland due to wage migration, and only four said that relatives live in Poland for several generations. So, more than 100 students are planning to see Poland whether they have family there or not. Tourism is a potentially attractive type of economic activity within the Ukrainian-Polish border but today level of providing its potential is still very low which are caused by differences in the provision due to: the instability of the institutes of tourism management; unsatisfactory scientific support of tourism development; insufficient cooperation between travel companies (Bilanyuk, 2012). Crossing a border is attractive for many tourists, even the crossing of a border by tourists that otherwise remain their own countries constitutes an additional attraction of a stay (Więckowski, 2008). Tourist policy in Poland is aimed at improvement of the system of domestic and foreign tourism through further efforts to create an attractive tourist image of the country in the world, infrastructure development, increasing attention to preservation cultural heritage of the country. Ukraine's position is not that perspective. Development of tourism industry in Ukraine in recent years is characterized by constant dynamics (Chetyrbuk, 2014). One of the most important characteristics of this trip is the affinity with the motherland and the family, and this is one of the most important human needs. Events that motivate tourists to travel that way are usually the events of the past or a certain attitude of the participants themselves. Participants of the trip can be divided into such group:

1. Participants of different events (wars, state conflicts, the formation of new countries etc.);

2. Children of those, with whom they have a family affair;

3. Those, which are in search of their roots and motherland (Kozovyy, 2017).

\section{CONCLUSIONS}

Sentimental tourism is a kind of tourism that continues to evolve. Unfortunately, the Ukrainian authorities do their best to ensure that Ukrainians, not only, travel abroad, but also feel disputed feelings and doubts about their role and motivation as a nation. Ukraine is very rich country, with unique history, culture and various touristic objects. Tourists arrive, with the hope of seeing the long-awaited progress, remain disappointed. Sentimental tourism is a kind of trip that attracts tourists with specific feelings. The area 
of sentimental tourism of the Ukrainian-Polish borderland covers significant areas of western Ukraine (Lviv and Volyn Oblasts) and eastern Poland (Lublin and Podkarpackie Voivodeships). The cultural aspect of sentimental tourism is not only in rest and restoring relationships with the family, but also in the education of the individual. Tourists enrich with knowledge of the history of their family and state. A significant number of tourist facilities contribute to a significant potential for the development of such tourism. There are many factors in Ukraine that have suspended the development of the state in the international arena (politics, culture, etc.), but the key is life according to the old Soviet rules that are not needed by anyone. This method is reflected in the level of attractiveness of Ukraine as a potentially rich country in all respects. Frequentlyfound phrases: "Years of independence", "Ukraine is independent" and so on... We live under the Soviet principles, in fact Poland evolves in the opposite direction.

\section{Aknowlegment}

Would like to thank department of tourism of both universities: Lviv State University of Physical Culture, Ivan Franko national university and also Lviv Polytechnic National University which have given a possibility to provide the survey.

\section{REFERENCES}

Baraniecki L., \& Wisniowa A. (2011). Sentimental Tourism Development in East-Central Europe, Wroclaw, p. 53. Bilanyuk O. P. (2012). Modern conditions and foreign tourism perspective of developing in Ukrainian-Polish relations, Lviv.

Chetyrbuk O. R. (2014). The analysis of the prospects for tourism development within the Ukrainian-Polish border, Geography and tourism, Kyiv, p. 29-34.

Feduń A. (2001). Główne kierunki ukraińsko-polskiej wspówpracy transgranicznej w warunkach procesu integracji europejskiej, Polska w systemie międzynarodowym w dobie integracji europejskiej (Main directions of Ukrainian-Polish cross-border cooperation in the conditions of the European integration process, Poland in the international system in the era of European integration), Puławy, p. 141-145.

Kalinowski M., \& Jacov M., (2015). Ormianski pasterz Lwowa ksiadz arcybiskup Jozef Teodorowicz na tle dziejow ormianskich (Armenian shepherd of Lviv priest Archbishop Jozef Teodorowicz against the background of Armenian history), Lublin-Lviv.

Komornicki T., \& Miszcuk A. (2010). Eastern Poland as the borderland of the European Union, Quastiones Geographicae 29 (2), Adam Mickiewicz University Press, Poznan, p. 61-62.

Kozovyy V. (2017). Sentimental tourism as the social happening and the most perspective kind of tourism within Ukrainian-Polish borderland, Vladimir Gnatyuk national university, Ternopol, p. 139.

Krawczyk Z. (2005). Globalne i krajowe tendencje w rozwoju turystyki [Global and national tendencies in the development of tourism], Wyzsza Szkola Ekonomiczna w Warszawie, Warszawa, p. 9-32.

Kuzik S. (2010). Theoretical Problems of Tourism: Socio-Geographic Approach: Monograph, Lviv.

Lilio I., Ferentsev Yu., Glazovy A., \& Chekhovskiy I. (2007). Travel Guide Car wand by Ukraine, Kyiv.

Miszczuk A. (2002). Pogranicze polsko-ukraińskie a polityka zagraniczna III RP (The Polish-Ukrainian borderland and the foreign policy of the Third Polish Republic), Warszawa.

Pecarchuk V. (2011). Protection and preservation of cultural heritage in the space of ethnic identification: trends of 1990-2000's, Chernihiv.

Savchuk B. (2004). Ukrainian ethnology, Ivano-Frankovsk.

Shabliy O. (2004). Geography: Worlds, Regions, Concepts, Kyiv.

Shapoval L. (2006). A dictionary of ethnographic (ethnological) concepts and terms, Poltava.

Tomczewska-Popowycz N.I. (2016). Tourist information system organization for sentimental tourism, Prague, p. 583-590.

Więckowski M. (2010). Tourism development in the borderlands of Poland, Geographia Polonica, Poland, p. 67-79.

Więckowski M. (2008). Selected aspects of tourism development in the borderland national parks, Geografia czlowieka [the contemporary research topics in Polish geography], Human geography, Instytut Geografii i Przestrzennego Zagospodarowania, PAN, p. 242.

http://www.zakono.rada.gov.ua/laws/show/616_208.

http://www.zakon2.rada.gov.ua/laws/show/1805-14.

https://en.wikipedia.org/wiki/Ukrainians_in_Poland.

Submitted:

06.04.2018
Revised:

01.10.2018
Accepted and published online 04.10.2018 